\title{
Performance of SMEs in Export Growth and Its Impact on Economy of Pakistan
}

\author{
Dr. Anwar Ali Shah \\ Dean Faculty of Commerce and Business Administration \\ University of Sindh-Jamshoro, Pakistan \\ Tariq Mehmood \\ Assistant Professor, IER, University of the Punjab, Pakistan \\ Muhammad Aamir Hashmi \\ Assistant Professor, IER, University of the Punjab, Pakistan \\ Syed Maqsood Shah \\ Assistant Professor, Department of Staistics, SALU-Khairpur, Pakistan \\ Faiz Muhammad Shaikh \\ Assistant Professor \\ SZABAC-Dokri-Larkana, Sindh, Pakistan \\ E-mail: faizanmy2000@hotmail.com
}

Received: January 21, 2011 Accepted: February 25, $2011 \quad$ doi:10.5539/ijbm.v6n7p287

\begin{abstract}
The present study was conducted to analyze the potential of SMEs in economy of Pakistan. Data were collected from 300 SMEs units by using Simple random technique. A structural questionnaire was developed to get the response from different SMEs units in Pakistan. Data were analyze by using SPSS-17.0 statistical software. It was revealed that SMEs in Rural Sindh has $45 \%$ contribution it can be increase by given facilities of marketing of those products. Moreover, SME exports are concentrated in labor-intensive sub-sectors where low wages are important to enhance the comparative competitive position of foreign markets and as well as SMEs do not necessarily export their products directly but through trade networks. The response rate was 90 percent only three units were sick units from last couple of years. It was further revealed that that potential contribution of SMEs to the sustainable growth of the Pakistan is large. Steps should be taken to ensure that more small firms are able to take advantage of government services. This may improve survival rates and stimulate development in lagging areas.

Keywords: Export, Growth, Potential, Rural Pakistan, SMEs

\section{Introduction}

It is a matter of fact that there are a lot of things in which large companies are experts while the small firms can better do some things also. If both, small and large firms do their business in which they get advantage, the welfare of the economy can be maximized and the state of specialization can be attained. When we focus on the impact of small as well as medium firms on the whole economy, it is difficult rather impossible for us to segregate their impacts from the impact of large corporations.

This issue remained a hot topic for centuries. Economists were of the view that it is a large firm, which participates actively in the economy and also shares a large amount of foreign exchange earnings. But their point of view changes when the countries like Taiwan, Japan and Korea developed on their small and medium based business. It is the crystal clear that these economies developed through the grass root level as small and medium enterprises belong to grass root. Those who believe that the large firms are only responsible for economic growth should keep in mind that the small vendors and small suppliers contribute heavily in the production of large firms. The reality on ground is that small firms are held responsible for making large firms to attain their targets. The progress and prosperity, which take place from the lower level, benefit all the classes of the society. The spill over impacts of SMEs proves to be ever lasting on the world's economy.
\end{abstract}


The situation differs in Pakistan. It is not more that 10 years that Govt. of Pakistan has established an institution named small and Medium Enterprise Authority (SMEDA) which is considered responsible to promote small and medium enterprises. SME sector is being neglected in Pakistan and so as the impacts of small and medium firms of Pakistan's economy. Pakistan is very potential market for SMEs and if undertaken in systematic way can prosper economy within no time. Pakistan has a considerable advantage in some areas which needs to be explained quickly to reap the benefits of exports. Such benefits can increase foreign exchange rates very positively to develop a favorable framework in all areas of progress.

The awareness like fishing, education, fruit, crops, garments, cotton, sugar cane, dates ginning, wood, auto and many other areas are the basic startups for many people. This research explains the potentialities of some areas and knowledge of how these areas can contribute towards Pakistan's economy by increasing the foreign exchange rates with reference to Sindh province. The high authorities and ministry of development and product should formulate some strategies to design practical policies with the cooperation of stakeholders, such policies will be flexible in enhancing the SMEDA plans and flourish SMEs activities at the larger scale. This will give a big boost to startup ideas and create cordial atmosphere of businesses. This will aid a lot more in understanding the export of Pakistan specially Sindh sector and improve our foreign exchange earnings. The main focus will be on SMEs' roles in economic growth and poverty alleviation through the increase of entrepreneurial and small scale business activities in the country especially in Sindh.

The third chapter provides a review of theoretical and empirical literature and the significant issues related to the understanding of Small and Medium Enterprises. Literature of Small \& Medium Enterprises is divided into two sections: International and National studies.

First section evaluates the existing international literature in regard to the development of SMEs, their role in economy specifically in exports, challenges and problems they are facing. Balasuriya (1992), Voerman, wedel and Zwart (1998), Muranda (2003), Hi Lin Hoon, Stoain (2007)'s studies support the concept of export oriented SMEs and highlight the positive relationship between Exports and SME's growth. While other studies by Majumder (2004), Kacker (2005), Saleh and Ndubisi (2006) and Tambunnan (2006) investigate the problems and challenges for SME's development. However, Branco (2003) argues the role and importance of small \& medium enterprises in economy.

National studies also correlate the presence of SMEs with several economic factors. Berry (1998), Mustafa and Khan (2005) and Khawaja (2006) outline the importance and potential of SME sector in Pakistan's economy. Husain (2003) discusses the role of SMEs in production of exports and the challenges they are facing in local market. Coy, Shipley, Omer and Khan (2007) determine the factors responsible for attaining success in small business in Pakistan.

The fourth chapter elaborates that SMEs constituted major share in the exports of Pakistan and contributing almost thirty percent to GDP on average during the time period of last five years. The main sectors included in SMEs were Footwear Industry, automotive parts, dairy industry, meat industry, leather industry, sports goods, fabrics, garments, bed wear, towels, tents and canvas, horticulture, cutlery, gems and jewellery, blankets and traveling rugs, furniture sector, pharmaceutical sector, services sector etc. Growth in SMEs sector has a direct impact on Pakistan's exports and vice versa, which is needed to be focused on priority basis.

The fifth chapter presents a glimpse of policies related to SME in Pakistan. It highlights the advantages and incentives given to SME sector in Pakistan and also throws light on the shortfalls in the policy formulation and implementation. It also provides a comparative study of policies related to small and medium enterprises in different countries. In the last chapter some recommendations and proposals have been made for the improvement and development of the small \& medium enterprises in Pakistan.

\section{Methodology}

\subsection{Data Collection and Research Methodology}

Data were collected from 300 SMEs business exports in Pakistan by using simple random technique and Structural questionnaire is the basic tool for measuring export potential. Data were analyze by using 17.0 Statistical software. The sources of the data are various issues of Economic Survey of Pakistan, database of Small \& Medium Enterprises (SMEDA), publication of International Trade Centre (ITC), annual reports of State bank of Pakistan, database of Trade Development Authority of Pakistan (TDAP), publications and databases of Federal Bureau of Statistics, trade polices from Ministry of Commerce of Pakistan, databases of Ministry of Finance, etc. Literature covers the research papers and studies available on the subject on internet and journals and libraries. The study is an attempt to present comparative analysis of the various SME based economies in the world specifically from Asia.

\section{Leather Industry}

(Finished Leather, 2002) stated that world's leading exporters of finished leather were Italy, Republic of Korea, Argentina, USA, Germany and Brazil. Further, Hong Kong, Italy, Germany, Spain and France were important buyers of finished leather from Pakistan in 2002. During 2002, Kasur (223) was main cluster city of finished 
leather in Pakistan followed by Sialkot (210), Karachi (174), Gujranwala (51), Multan (43), Sheikhupura (28), Lahore (15), Sahiwal (8), Faisalabad (7), Peshawar (6), Sargodha (5) etc.

Following Table shows export of Leather Products during 2001-06. Export of leather Tanned shows variation during 2001-06 as shown in Figure. Exports of leather tanned decreases from US\$239,934 thousand in 2001-02 to US\$234,774 thousand in 2002-03 showing fall in exports by 2.15 percent during the same time period. Then, again exports of leather tanned shows increasing trend in two consecutive years of 2003-04 and 2004-05 by 7.21 percent and 20.63 percent respectively. However, it depicts decrease by 3.69 percent in 2005-06. In the Table 3.6 export of leather gloves from Pakistan shows increasing trend except the year of 2005-06. In 2005-06 export of leather gloves stood at US\$151,459 thousand as compare to US\$164,333 thousand in 2004-05 decreased by 7.8 percent during the same time period. Major buyers of Pakistan for the product of leather gloves are USA, Germany and France with their share at 22.99 percent, 11.64 percent and 7.85 percent respectively in 2005-06.

Export of leather products in the category of apparel \& clothing increased except 2002-03. The value of Export of Pakistan in this product stood at US\$ 501,786 thousand in 2005-06 as compare to US\$ 321,341 thousand in 2001-02, with an increase of 56.15 percent over the period. While Pakistan's export of leather manufactures n.s. shows growth of 558.21 percent during 2001-06.

\section{Conclusion}

The overall in-depth sample showed a high degree of concern over economic problems but that concern did vary. The constraint which was most uniformly faced was political instability followed by (the related constraint) uncertainty in the business climate. Those in Sindh were significantly more concerned about their lack of information on their competition and about the lack of market for their products than their peers in Punjab or NWFP. Even more dramatically, all those interviewed in Sindh were severely threatened by uncertainty in the business climate and by climatic disasters while their colleagues elsewhere were much less likely to rank these as serious constraints. More than $80 \%$ of them thought that government corruption was serious problem for them as well.

They did not perceive that there was increasing credit available inspite of SMEDA or SBFC or that the government had begun to be interested in their welfare and had begun to devise policies to support them. More than half the respondent entrepreneurs thought that government support had substantially decreased.

Entrepreneurs' concern regarding the changes in Government policies and taxes. What may be seen by economists as having positive effects on SMEs may not be equally valued by entrepreneurs. Thus, most responded strongly that government taxing and pricing policies were serious constraints to their establishments. Very few (12\% of the entire set of respondents) felt that government support had increased and in fact, more than $70 \%$ felt it had decreased substantially. Entrepreneurs in all provinces share a grave concern about the lack of credit and the conditions required for obtaining what credit there is. Few responded "do not know" to any questions and few took the lukewarm options. Most felt strongly about what they wanted and needed for their businesses.

\section{References}

Akizawa, Hikari., \& Kijima, Kyoichi, Kijima. Theory \& Research: Internet-based Entrepreneurial Networking to Evolve the Japanese Industrial Structure. Department of Value and Decision Science, Tokyo Institute of Technology, Japan.

APO. (2000). Small and Medium Enterprises in Hong Kong, Reforms from Developing Countries. Export Orientation for Small and Medium Enterprises in Exports, APO.

Balasuriya, Anton. (2 ${ }^{\mathrm{ND}}$ QTR/1992). Technonet Asia, Newsletter, Singapore.

Bardrinath, R. (1997). The SME and the Global Market Place. International Trade Centre UNCTAD/WTO Geneva, Switzerland.

Castel-Branco, Carlos Nuno. (2003). A Critique of SME-led Approaches to Economic Development. Islamic Chamber of Trade and Industry, Mozambique

Chen, Edward K.Y. (1986). Small Industry in Asia's Export- Oriented Growth. Asian Productivity Organization, Tokyo

Coy, Steven P, Shipley, Margaret F, Omer, Khursheed \& Khan, Rao Nisar A. (2007). Factors Contributory to Success: A Study of Pakistan's Small Business Owners. Journal of Developmental Entrepreneurship.

Edwards, Tim., Rick Delbridge and Max Munday. (2005). Understanding Innovation in Small and medium-sized Enterprises: A Process Manifesto. Cardiff University, Aberconway Building, Colum Drive, Cardiff CF 103 EU, $\mathrm{UK}$.

Federal Bureau of Statistics. (2005). Pakistan Statistical Year Book

Germidis, D. (1980). International subcontracting: a new form of investment. OECD, Paris.

Government of Pakistan, Ministry of Finance, Pakistan Economic Survey, (Various Issues) 
Government of Pakistan, Small and Medium Enterprise Development Authority (SMEDA), Sector Brief: Towels and Cleaning Cloths, Revised on July 12, 2002

Government of Pakistan, Small and Medium Enterprise Development Authority (SMEDA), Sector Brief: Bed-wear \& Linen, Revised on July 12, 2002

Government of Pakistan, Small and Medium Enterprise Development Authority (SMEDA), Sector Brief: Leather Footwear, Revised on July 12, 2002

Government of Pakistan, Small and Medium Enterprise Development Authority (SMEDA), Sector Brief: Gems \& Jewellery, Revised on July 12, 2002

Government of Pakistan, Small and Medium Enterprise Development Authority (SMEDA), Sector Brief: Marine Fisheries, Revised on July 12, 2002

Government of Pakistan, Small and Medium Enterprise Development Authority (SMEDA), Sector Brief: Finished Leather, Revised on July 12, 2002

Government of Pakistan, Small and Medium Enterprise Development Authority (SMEDA), Sector Brief: Curtains \& Furnishings, Revised on July 12, 2002

Government of Pakistan, Small and Medium Enterprise Development Authority (SMEDA), Sector Brief: Apparel, Revised on July 12, 2002

Government of Pakistan, Small and Medium Enterprise Development Authority (SMEDA), Sector Brief: Blankets, Revised on July 12, 2002

Government of Pakistan, Small and Medium Enterprise Development Authority (SMEDA), Sector Brief: Canvas, Revised on July 12, 2002

Government of Pakistan, Small and Medium Enterprise Development Authority (SMEDA), Sector Brief: Ceramics, Revised on July 12, 2002

Government of Pakistan, Small and Medium Enterprise Development Authority (SMEDA), Sector Brief: Horticulture

Government of Pakistan, Small and Medium Enterprise Development Authority (SMEDA), Sector Brief: Cotton \& Ginning

Government of Pakistan, Small and Medium Enterprise Development Authority (SMEDA), Sector Brief: Dairy

Government of Pakistan. (2002). Small and Medium Enterprise Development Authority (SMEDA), Sector Brief: Cutlery, Revised on July 12, 2002.

Halbach, AJ. (1989). Multinational enterprises and subcontracting in the third world: a study of inter-industry linkages, International Labour Office, Geneva.

Hoon, Ho Lin, "Internationalization of Small Industry" National Productivity Board, Singapore

Howard, Robert. (1990). Can Small Business Help Countries Compete? Harvard Business Review November-December 1990 (pp 80-103)

Husain, Ishrat. (2004). Financial Sector Reforms and Pro Poor Growth: a cars Study of Pakistan. Presidential Address at the Annual General Meeting of the Institute of Bankers Pakistan held at Karachi.

Husain, Ishrat. (2005). SME Financing Issues and Strategies. Welcome Address at the conference on SME Financing Issues and Strategies held in Lahore on May 9.

Husain, Ishrat. (2005). SME Financing Issues and Strategies. Welcome Address at the conference on SME Financing Issues and Strategies held in Lahore on May 9.

Jaitle, T.N. (1981). Export Promotion of Selected Small Industry Products: Asian Experience. Asian Productivity Organization, Tokyo

Kacker Stuti. (2005). Overcoming Barriers to Innovation for Indian SMEs. Ministry Small Scale Industries, New Delhi, India.

Khawaja, Shoaib. (2006). Unleashing the Growth Potential of SMEs in Pakistan through Productivity Enhancement. Pakistan Development Forum - 2006.

Kim, Young-Duck. (2000). Policies, Reforms and Evaluation of SME Export Experiences of Republic of Korea. Export Orientation for Small and Medium Enterprises in Exports, APO.

Klerg, GJ de., \& Havenga, JJD. SME Networks and Clusters and their Impact on Economic Growth: An Explanatory Overview of Africa. North-West University, Potchefstroom, South Africa.

Kohata., K. (2006). SME Policy in USA, Japan, Korea and Thailand. The Asian Development Bank (ADB) May 2006.

Majumder, Rajarshi. (2004). Productivity Growth in Small Enterprises - Role of Inputs, Technological Progress and Learning by Doing" MPRA Paper No. 4848, West Bengal 
Manjor, Asir. (2002). "Garment Industry in Pakistan" In Gopal Joshi (eds.) Garments Industry in South Asia Rags or Riches?: Competitiveness, productivity and job quality in the post-MFA environment. India: International labour organization 2002

Mcclean, Rowan, Wajid, Majid Ali. (February 2007). Services Exports: National Road Map for Pakistan Geneva, Switzerland: International Trade Centre (UNCTAD/WTO)

Muranda, Zororo. (2003). Relationships between Firm Characteristics and Export Constraints in SME Exporters. Business Studies Deportment, University of Zimbabwe.

Nihaya, Wongtada. (2000). Opportunity and Threat to Potential SME Export: Experience of Thailand. Export Orientation for Small and Medium Enterprises in Exports, APO.

OECD. (2002). The OECD Small and Medium Enterprises Outlook, Country Profiles; Japan, Korea, Turkey, OECD.

Office of SMEs Promotion (OSMEP)/ DIP/MOI and Institute for SMEs Development (ISMBD), Thailand. [Online] Available: www.sme.go.th \& www.smethai.net

Pakistan Automotive Manufacturer Association (PAMA), Data Base, 2005-06

Paskaleva, K., \& Shapira, G. (2006). Innovation and SMEs: Some Asian Experiences. [Online] Available: http://www.itas.fzk.de/tatup/061/pash06a.htm

Pichler, J. Hanns., and Peter Voithover. (2006). SME Strategic Behavior and Attitudes towards Cooperation and Network. University of Lapland, Rovaniemi, Finland.

Saleh, Ali Salman and Ndubisi, Nelson Oly. (2006). An Evaluation of SME Development in Malaysia. International Review of Business Research Papers, 1-14. Malaysia.

Saxenian, A. (1994). Regional Advantage. MA: Harvard University Press.

Scholar, Morten, Bijil, Bastiaan, Butt Madiha and Haque, Inaam ul. (September 2007). The Sports Goods Sector In Pakistan: Export Performance And Potential \& Implication Of The WTO Agreements Geneva, Switzerland: International Trade Centre (UNCTAD/WTO)

Scholar, Morten, Elferink, Jan Oude, Bijil Bastiaan, Butt Madiha and Haque, Inaam ul. (September 2007). The Automotive Parts Sector In Pakistan: Export Performance and Potential \& Implication Of The WTO Agreements Geneva, Switzerland: International Trade Centre (UNCTAD/WTO)

Scholar, Morten, Lodhi, Javed, Roofthooft, Ward, Bijil, Bastiaan, Butt Madiha and Haque, Inaam ul. (August 2007). The Pharmaceutical Sector In Pakistan: Export Performance And Potential \& Implication Of The WTO Agreements Geneva, Switzerland: International Trade Centre (UNCTAD/WTO)

Scholar, Morten, Tissari, Jukka, Bijil Bastiaan, Butt Madiha and Haque, Inaam ul. (August 2007). The Furniture Sector in Pakistan: Export Performance And Potential \& Implication of the WTO Agreements Geneva, Switzerland: International Trade Centre (UNCTAD/WTO)

Scholar, Morten, Zakaria, Fasim, Bijil Bastiaan, Butt Madiha and Haque, Inaam ul. (September 2007). The Footwear Sector in Pakistan: Export Performance And Potential \& Implication Of The WTO Agreements Geneva, Switzerland: International Trade Centre (UNCTAD/WTO)

Small and Medium Business Administration (SMBA). Korea. [Online] Available: www.smba.go.kr

Small and Medium Enterprise Agency (SMEA). Japan. [Online] Available: www.chusho.meti.go.jp

Small and Medium Enterprise Authority (SMEDA). [Online] Available: www.smeda.org.pk

Stoian, Maria-Cristina. (2002). Managerial Determinants and Their Influence Upon The Export Behavior Of The Firm Case-Studies Of Catalan Exporting SMEs. Spain: University of Barcelona.

Tambunnan, Tulus. (2007). Trade and Investment Liberalization Effects on SME Development: A literature Review and a Case Study of Indonesia. Asia-Pacific Research and Training Network on Trade, 42: Indonesia

Trade Development Authority of Pakistan. (2005-06). TDAP, Export Summary. (2005-06). [Online] Available: http://www.epb.gov.pk

Trade Map. (2006). Data Base, 2006.

Voerman, J.A., Wedel, M., and Zwart, P.S. (1998). Export Market Information Behavior of SMEs: The Influence of Firm Characteristics. SOM Research School: University of Groningen.

Wang, Dr. Yue. (2007). Towards A Conceptualization of International Subcontracting. Monash Business Review Volume 3 Issue 1-April 2007. School Of Organization and Management, University of New South Wales. April 2007.

Winkelmann, Thorsten. (1996). Internationalization Strategies of Small and Medium-Sized Suppliers in a Global Economy. University of Gottingen, Gottingen, Germany. 
Table 1. Contribution of SME in Manufacturing and GDP of Pakistan

\begin{tabular}{|c|c|c|c|}
\hline Year & SME as a percentage of GDP & $\begin{array}{c}\text { Percentage share of } \\
\text { SME Manufacturing } \\
\text { in Value Addition }\end{array}$ & $\begin{array}{c}\text { SME as a percentage } \\
\text { of Industrial Labour }\end{array}$ \\
\hline $1994-95$ & 5.79 & 31.26 & 81 \\
\hline $1995-96$ & 5.90 & 32.8 & 80 \\
\hline $1996-97$ & 4.7 & 27 & 80 \\
\hline $1997-98$ & - & 35 & - \\
\hline $1998-99$ & 5 & - & 80 \\
\hline $1999-00$ & - & - & - \\
\hline $2000-01$ & - & - & 80 \\
\hline $2001-02$ & 30 & 30 & 80 \\
\hline $2002-03$ & 30 & & \\
\hline
\end{tabular}

Source: Economic Survey of Pakistan, Various Issues

Table 2. Shows production of automotive sector during last thirteen years

\begin{tabular}{|l|r|r|r|r|r|r|r|}
\hline Year & \multicolumn{1}{|c|}{ Cars } & Trucks & \multicolumn{1}{l|}{ Bus } & Jeep \& LCV & Pic-Up/LCV & Farm Tractor & Motor Cycles \\
\hline $\mathbf{1 9 9 5 - 9 6}$ & 33,419 & 2,994 & 474 & 2,274 & 2,682 & 16,093 & - \\
\hline $\mathbf{1 9 9 6 - 9 7}$ & 37,032 & 2,917 & 456 & 792 & 4,553 & 10,417 & 106,797 \\
\hline $\mathbf{1 9 9 7 - 9 8}$ & 38,676 & 1,683 & 591 & 657 & 4,843 & 14,144 & 92,978 \\
\hline $\mathbf{1 9 9 8 - 9 9}$ & 42,927 & 1,083 & 1,124 & 622 & 3,834 & 26,644 & 87,504 \\
\hline $\mathbf{1 9 9 9 - 0 0}$ & 35,332 & 913 & 1,460 & 380 & 3,785 & 24,559 & 86,959 \\
\hline $\mathbf{2 0 0 0 - 0 1}$ & 41,556 & 912 & 1,326 & 459 & 4,982 & 31,635 & 108,850 \\
\hline $\mathbf{2 0 0 1 - 0 2}$ & 42,679 & 1,134 & 1,086 & 564 & 5,900 & 23,801 & 120,627 \\
\hline $\mathbf{2 0 0 2 - 0 3}$ & 66,432 & 1,929 & 1,296 & 374 & 7,815 & 26,240 & 175,169 \\
\hline $\mathbf{2 0 0 3 - 0 4}$ & 103,662 & 2,022 & 1,380 & 807 & 8,888 & 35,770 & 303,383 \\
\hline $\mathbf{2 0 0 4 - 0 5}$ & 133,722 & 3,204 & 1,762 & 1,564 & 16,294 & 43,200 & 416,189 \\
\hline $2005-06$ & 170,487 & 4,518 & 825 & 2,472 & 19,152 & 48,887 & 520,124 \\
\hline
\end{tabular}

Table 3. Export of dairy products from Pakistan during 1999-04

(Thousand rupees)

\begin{tabular}{|c|c|c|c|}
\hline Year & Milk and cream & Butter & Eggs \\
\hline $1999-00$ & 54,517 & 1,560 & 18,631 \\
\hline $2000-01$ & 79,445 & 3,621 & 68,627 \\
\hline $2001-02$ & 102,247 & 5,770 & 112,072 \\
\hline $2002-03$ & 290,488 & 5,578 & 90,238 \\
\hline $2003-04$ & 444,506 & 3,003 & 113,534 \\
\hline
\end{tabular}

Source: Pakistan Statistical Year Book, 2005

\begin{tabular}{|l|c|c|c|c|c|c|c|c|}
\hline Year & \multicolumn{2}{|c|}{ Leather Tanned } & \multicolumn{2}{c|}{ Leather Gloves } & \multicolumn{2}{c|}{$\begin{array}{c}\text { Apparel \& Clothing } \\
\text { of Leather }\end{array}$} & \multicolumn{2}{c|}{$\begin{array}{c}\text { Leather } \\
\text { Manufactures N.S. }\end{array}$} \\
\cline { 2 - 9 } & Value & $\begin{array}{c}\text { Quantity } \\
(000 \text { SQM })\end{array}$ & Value & $\begin{array}{c}\text { Quantity } \\
(000 \text { DOZ) }\end{array}$ & Value & $\begin{array}{c}\text { Quantity } \\
(000 \text { DOZ })\end{array}$ & Value & Quantity \\
\hline $2001-02$ & 239,934 & 17,290 & 51,324 & 2,943 & 321,341 & 783 & 10,530 & - \\
\hline $2002-03$ & 234,774 & 15,349 & 56,969 & 2,718 & 232,316 & 564 & 97,262 & - \\
\hline $2003-04$ & 251,693 & 16,050 & 70,722 & 2,709 & 323,656 & 709 & 19,965 & - \\
\hline $2004-05$ & 303,606 & 18,435 & 164,333 & 5,649 & 329,272 & 737 & 33,169 & - \\
\hline $2005-06$ & 292,394 & 17,377 & 151,459 & 4,498 & 501,786 & 1,050 & 69,309 & - \\
\hline
\end{tabular}

Source: Trade Development Authority of Pakistan, TDAP <http://www.epb.gov.pk> 
Table 4. Export of Sports Goods from Pakistan during 2001-06

(US\$ 000)

\begin{tabular}{|c|c|c|}
\hline Year & Sports Goods & \% Change \\
\hline $2001-02$ & 304,478 & - \\
\hline $2002-03$ & 335,173 & 10.08 \\
\hline $2003-04$ & 324,751 & $(3.11)^{*}$ \\
\hline $2004-05$ & 307,129 & $(5.43)$ \\
\hline $2005-06$ & 343,329 & 11.79 \\
\hline
\end{tabular}

* Figures in brackets shows negative values

Source: Trade Development Authority of Pakistan, TDAP <http://www.epb.gov.pk>

Table 5. Export of Fabrics from Pakistan during 2001-06

(US\$ 000)

\begin{tabular}{|c|c|c|c|c|}
\hline Year & Cotton Fabrics & $\begin{array}{c}\text { \% Change of Cotton } \\
\text { Fabrics }\end{array}$ & $\begin{array}{c}\text { Knitted/Croacheted } \\
\text { Fabrics }\end{array}$ & $\begin{array}{c}\text { \%Change } \\
\text { Knitted/Croacheted } \\
\text { Fabrics }\end{array}$ \\
\hline $2001-02$ & $1,130,828$ & - & 72,420 & - \\
\hline $2002-03$ & $1,345,650$ & 19 & 59,466 & $(17.89)^{*}$ \\
\hline $2003-04$ & $1,711,492$ & 27.19 & 54,923 & $(7.64)$ \\
\hline $2004-05$ & $1,862,886$ & 8.85 & 187,158 & 240.76 \\
\hline $2005-06$ & $2,108,183$ & 13.17 & 51,378 & 72.55 \\
\hline
\end{tabular}

* Figures in brackets shows negative values

Source: Trade Development Authority of Pakistan, TDAP <http://www.epb.gov.pk>

Table 6. SMEs contribution in Export of Garments from Pakistan during 2001-06

(US\$ 000)

\begin{tabular}{|c|c|c|c|c|}
\hline Year & $\begin{array}{c}\text { Ready-Made } \\
\text { Garments excl. } \\
\text { Leather } \\
\text { Garment }\end{array}$ & $\begin{array}{c}\text { \% change } \\
\text { Ready-Made } \\
\text { Garments excl. } \\
\text { Leather } \\
\text { Garment }\end{array}$ & Knitwear (Hosiery) & $\begin{array}{c}\text { \% Change Knitwear } \\
\text { (Hosiery) }\end{array}$ \\
\hline $2001-02$ & 874,954 & - & 845,943 & - \\
\hline $2002-03$ & $1,092,607$ & 24.88 & $1,146,674$ & 35.55 \\
\hline $2003-04$ & 993,322 & $(9.09)^{*}$ & $1,458,736$ & 27.21 \\
\hline $2004-05$ & $1,087,954$ & 9.53 & $1,635,033$ & 12.09 \\
\hline $2005-06$ & $1,309,990$ & 20.41 & $1,751,494$ & 7.12 \\
\hline
\end{tabular}

* Figures in brackets shows negative values

Source: Trade Development Authority of Pakistan, TDAP <http://www.eph.gov.pk>

Table 7. Export of Bed Wear from Pakistan during 2001-06

(US\$ 000)

\begin{tabular}{|c|c|c|}
\hline Year & Bed Wear & \% Change Bed Wear \\
\hline $2001-02$ & 918,558 & - \\
\hline $2002-03$ & $1,329,064$ & 44.69 \\
\hline $2003-04$ & $1,383,334$ & 4.08 \\
\hline $2004-05$ & $1,449,533$ & 4.79 \\
\hline $2005-06$ & $2,038,064$ & 40.60 \\
\hline
\end{tabular}

Source: Trade Development Authority of Pakistan, TDAP <http://www.epb.gov.pk> 
Table 8. SPSS RESULTS and analysis

PART-1

\begin{tabular}{|c|c|c|c|}
\hline & & Frequency & Percent \\
\hline Missing & System & 51 & 100.0 \\
\hline
\end{tabular}

Nature of the Business

\begin{tabular}{|c|c|c|c|c|c|c|c|c|}
\hline \multirow{12}{*}{ Valid } & & & \multicolumn{2}{|c|}{ Frequency } & \multicolumn{2}{|c|}{ Percent } & Valid Percent & Cumulative Percent \\
\hline & \multirow{11}{*}{\multicolumn{2}{|c|}{$\begin{array}{l}\text { Bicycles } \\
\text { Fabrication/M'facture } \\
\text { Food Processing } \\
\text { Footwear } \\
\text { Fruits \& vegetables } \\
\text { Jewellery \& Gems } \\
\text { Knitwear } \\
\text { OEM } \\
\text { Sports goods } \\
\text { Surgical } \\
\text { Total }\end{array}$}} & \multicolumn{2}{|c|}{3} & \multicolumn{2}{|c|}{5.9} & 5.9 & 5.0 \\
\hline & & & \multicolumn{2}{|l|}{11} & \multicolumn{2}{|c|}{21.6} & 21.6 & 27.0 \\
\hline & & & \multicolumn{2}{|l|}{7} & \multicolumn{2}{|c|}{13.7} & 13.7 & 41.0 \\
\hline & & & \multicolumn{2}{|l|}{4} & \multicolumn{2}{|c|}{7.8} & 7.8 & 49.0 \\
\hline & & & \multicolumn{2}{|l|}{4} & \multicolumn{2}{|l|}{7.8} & 7.8 & 56.0 \\
\hline & & & \multicolumn{2}{|l|}{4} & \multicolumn{2}{|l|}{7.8} & 7.8 & 64.0 \\
\hline & & & \multicolumn{2}{|l|}{5} & \multicolumn{2}{|l|}{9.8} & 9.8 & 74.0 \\
\hline & & & \multicolumn{2}{|l|}{5} & \multicolumn{2}{|l|}{98} & 9.8 & 84.0 \\
\hline & & & \multicolumn{2}{|l|}{3} & \multicolumn{2}{|l|}{5.9} & 5.9 & 90.0 \\
\hline & & & \multicolumn{2}{|l|}{5} & \multicolumn{2}{|l|}{9.8} & 9.8 & 100.0 \\
\hline & & & 51 & & 100 & & 100.0 & \\
\hline & & & & Type & of $\mathrm{O}$ & ner & & \\
\hline & & Fre & uency & Perc & & $\mathbf{V a}$ & d Percent & Cumulative Percent \\
\hline Valid & Proprietorship & 23 & & 45.1 & & 45. & & 5.1 \\
\hline & Partnership & 8 & & 15.7 & & 15. & & 0.8 \\
\hline & Private Ltd & 18 & & 35.3 & & 35. & & 6.1 \\
\hline & Public Ltd & 2 & & 3.9 & & 3.9 & & 00.0 \\
\hline & Total & 51 & & 100. & & 100 & & \\
\hline
\end{tabular}

Local Share

\begin{tabular}{|c|c|c|c|c|c|}
\hline & & Frequency & Percent & Valid Percent & Cumulative Percent \\
\hline \multirow{4}{*}{ Valid } & \multirow{4}{*}{$\begin{array}{l}30 \% \\
50 \% \\
100 \% \\
\text { Total } \\
\end{array}$} & 1 & 2.0 & 2.0 & 2.0 \\
\hline & & 2 & 3.9 & 3.9 & 5.9 \\
\hline & & 48 & 94.1 & 94.1 & 100.0 \\
\hline & & 51 & 100.0 & 100.0 & \\
\hline \multicolumn{6}{|c|}{ Foreign Share } \\
\hline & & Frequency & Percent & Valid Percent & Cumulative Percent \\
\hline \multirow{3}{*}{$\begin{array}{l}\text { Valid } \\
\text { Missing } \\
\text { Total }\end{array}$} & \multirow{3}{*}{$\begin{array}{l}50 \% \\
\text { System }\end{array}$} & 2 & 3.9 & 100.0 & 100.0 \\
\hline & & 49 & 96.1 & & \\
\hline & & 51 & 100.0 & & \\
\hline
\end{tabular}

What percentage of Your Materials and Parts are Imported?

\begin{tabular}{|ll|l|l|l|l|}
\hline & Frequency & Percent & Valid Percent & Cumulative Percent \\
\hline Valid & $50-80 \%$ & 6 & 11.8 & 13.0 & 13.0 \\
\cline { 3 - 6 } & $30-50 \%$ & 13 & 25.5 & 28.3 & 41.0 \\
\cline { 3 - 6 } & $10-30 \%$ & 7 & 13.7 & 15.2 & 56.0 \\
\cline { 3 - 6 } & Less than $10 \%$ & 19 & 37.3 & 41.3 & 97.0 \\
\cline { 3 - 6 } & Nil & 1 & 2.0 & 2.2 & 100.0 \\
\cline { 3 - 6 } & Total & 46 & 90.2 & 100.0 & \\
\cline { 3 - 6 } Missing & System & 5 & 9.8 & & \\
\cline { 3 - 6 } Total & 51 & 100.0 & & \\
\hline
\end{tabular}

Do you have Your Own Brand Name?

\begin{tabular}{|c|c|c|c|c|c|}
\hline & & Frequency & Percent & Valid Percent & Cumulative Percent \\
\hline \multirow[t]{3}{*}{ Valid } & \multirow{5}{*}{$\begin{array}{l}\text { Yes } \\
\text { No } \\
\text { Total } \\
\text { System }\end{array}$} & 16 & 31.4 & 33.3 & 33.3 \\
\hline & & 32 & 62.7 & 66.7 & 100.0 \\
\hline & & 48 & 94.1 & 100.0 & \\
\hline \multirow{2}{*}{$\begin{array}{l}\text { Missing } \\
\text { Total }\end{array}$} & & 3 & 5.9 & & \\
\hline & & 51 & 100.0 & & \\
\hline
\end{tabular}


PART-2

\begin{tabular}{|c|c|c|c|c|c|}
\hline & & & \multicolumn{2}{|c|}{ Frequency } & Percent \\
\hline Missing & \multicolumn{2}{|c|}{ System } & 51 & & 100.0 \\
\hline \multicolumn{6}{|c|}{ Difficulty in obtaining the Financing } \\
\hline & & Frequency & Percent & Valid Percent & Cumulative Percent \\
\hline \multirow[t]{4}{*}{ Valid } & Severe & 18 & 35.3 & 36.0 & 36.0 \\
\hline & Moderate & 19 & 37.3 & 38.0 & 74.0 \\
\hline & Slight or None & 13 & 25.5 & 26.0 & 100.0 \\
\hline & Total & 50 & 98.0 & 100.0 & \\
\hline Missing & System & 1 & 2.0 & & \\
\hline Total & & 51 & 100.0 & & \\
\hline
\end{tabular}

Increased Overall Production Costs

\begin{tabular}{|ll|l|l|l|l|}
\hline & & Frequency & Percent & Valid Percent & Cumulative Percent \\
\hline Valid & Severe & 24 & 47.1 & 48.0 & 48.0 \\
& Moderate & 17 & 33.3 & 34.0 & 82.0 \\
& $\begin{array}{l}\text { Slight } \text { or } \\
\text { None }\end{array}$ & 9 & 17.6 & 18.0 & 100.0 \\
& Total & 50 & 98.0 & 100.0 & \\
Missing & System & 1 & 2.0 & & \\
Total & & 51 & 100.0 & & \\
\hline
\end{tabular}

Increased Costs of Materials and Parts

\begin{tabular}{|ll|l|l|l|l|}
\hline & & Frequency & Percent & Valid Percent & Cumulative Percent \\
\hline Valid & Severe & 25 & 49.0 & 50.0 & 50.0 \\
& Moderate & 14 & 27.5 & 28.0 & 78.0 \\
& Slight or None & 11 & 21.6 & 22.0 & 100.0 \\
& Total & 50 & 98.0 & 100.0 & \\
Missing & System & 1 & 2.0 & & \\
Total & & 51 & 100.0 & & \\
\hline
\end{tabular}

Availability of Skilled Workers

\begin{tabular}{|ll|l|l|l|l|}
\hline & & Frequency & Percent & Valid Percent & Cumulative Percent \\
\hline Valid & Severe & 12 & 23.5 & 24.0 & 24.0 \\
& Moderate & 23 & 45.1 & 46.0 & 70.0 \\
& Slight or None & 15 & 29.4 & 30.0 & 100.0 \\
& Total & 50 & 98.0 & 100.0 & \\
Missing & System & 1 & 2.0 & & \\
Total & & 51 & 100.0 & & \\
\hline
\end{tabular}

Availability of Unskilled Workers

\begin{tabular}{|ll|l|l|l|l|}
\hline & & Frequency & Percent & Valid Percent & Cumulative Percent \\
\hline Valid & Severe & 11 & 21.6 & 22.0 & 22.0 \\
& Moderate & 1 & 37.3 & 38.0 & 60.0 \\
& Slight or None & 20 & 39.2 & 40.0 & 100.0 \\
& Total & 50 & 98.0 & 100.0 & \\
Missing & System & 1 & 2.0 & & \\
Total & & 51 & 100.0 & & \\
\hline
\end{tabular}

Labor Relation/Union Actions

\begin{tabular}{|ll|l|l|l|l|}
\hline & & Frequency & Percent & Valid Percent & Cumulative Percent \\
\hline Valid & Severe & 15 & 29.4 & 30.0 & 30.0 \\
& Moderate & 12 & 23.5 & 24.0 & 54.0 \\
& Slight or None & 23 & 45.1 & 46.0 & 100.0 \\
& Total & 50 & 98.0 & 100.0 & \\
Missing & System & 1 & 2.0 & & \\
Total & & 51 & 100.0 & & \\
\hline
\end{tabular}


Production Technology

\begin{tabular}{|l|l|c|c|c|c|}
\hline \multirow{7}{*}{ Valid } & & Frequency & Percent & Valid Percent & Cumulative Percent \\
& $\begin{array}{l}\text { Better than } \\
\text { Competitors }\end{array}$ & 20 & 39.2 & 40.0 & 40.1 \\
\cline { 2 - 6 } & $\begin{array}{l}\text { About the same } \\
\text { as Competitors }\end{array}$ & 24 & 47.1 & 48.0 & 88.0 \\
\cline { 2 - 6 } & $\begin{array}{l}\text { Not so Good as } \\
\text { Competitors }\end{array}$ & 4 & 7.8 & 8.0 & 96.1 \\
\cline { 2 - 6 } & Not sure & 2 & 3.9 & 4.0 & 100.0 \\
\cline { 2 - 6 } & Total & 50 & 98.0 & 100.0 & \\
\hline Missing & System & 1 & 2.0 & & \\
\hline Total & \multicolumn{5}{|c|}{ Product Quality } \\
\hline
\end{tabular}

\begin{tabular}{|l|l|c|c|c|c|}
\hline & & Frequency & Percent & Valid Percent & Cumulative Percent \\
\hline Valid & $\begin{array}{l}\text { Better than } \\
\text { Competitors }\end{array}$ & 22 & 43.1 & 44.0 & 44.1 \\
\cline { 2 - 6 } & $\begin{array}{l}\text { About the same } \\
\text { as Competitors }\end{array}$ & 21 & 41.2 & 42.0 & 86.1 \\
\cline { 2 - 6 } & $\begin{array}{l}\text { Not so Good as } \\
\text { Competitors }\end{array}$ & 4 & 7.8 & 8.0 & 94.0 \\
\cline { 2 - 6 } & Not sure & 3 & 5.9 & 6.0 & 100.0 \\
\cline { 2 - 6 } & Total & 50 & 98.0 & 100.0 & \\
\hline Missing & System & 1 & 2.0 & & \\
\hline Total & & 51 & 100.0 & & \\
\hline
\end{tabular}

Product Design/Development

\begin{tabular}{|l|l|l|l|l|l|}
\hline & & Frequency & Percent & Valid Percent & Cumulative Percent \\
\hline Valid & $\begin{array}{l}\text { Better than } \\
\text { Competitors }\end{array}$ & 19 & 37.3 & 38.0 & 38.0 \\
\cline { 2 - 6 } & $\begin{array}{l}\text { About the same } \\
\text { as Competitors }\end{array}$ & 25 & 49.0 & 50.0 & 88.0 \\
\cline { 2 - 6 } & $\begin{array}{l}\text { Not so Good as } \\
\text { Competitors }\end{array}$ & 4 & 7.8 & 8.0 & 96.1 \\
\cline { 2 - 6 } & Not sure & 2 & 33.9 & 4.0 & 100.0 \\
\cline { 2 - 6 } & Total & 50 & 98.0 & 100.0 & \\
\hline Missing & System & 1 & 2.0 & & \\
\hline Total & & 51 & 100.0 & & \\
\hline
\end{tabular}

Product Range / Diversity

\begin{tabular}{|c|c|c|c|c|c|}
\hline & & Frequency & Percent & Valid Percent & Cumulative Percent \\
\hline Valid & $\begin{array}{c}\text { Better than } \\
\text { Competitors }\end{array}$ & 19 & 37.3 & 38.0 & 38.1 \\
\cline { 2 - 6 } & $\begin{array}{c}\text { About the same } \\
\text { as Competitors }\end{array}$ & 26 & 51.0 & 52.0 & 90.0 \\
\cline { 2 - 6 } & $\begin{array}{c}\text { Not so Good as } \\
\text { Competitors }\end{array}$ & 3 & 5.9 & 6.0 & 96.1 \\
\cline { 2 - 6 } & Not sure & 2 & 3.9 & 4.0 & 100.0 \\
\cline { 2 - 6 } & Total & 50 & 98.0 & 100.0 & \\
\hline Missing & System & 1 & 2.0 & & \\
\hline Total & & 51 & 100.0 & & \\
\hline
\end{tabular}


Product Image / Brand Image

\begin{tabular}{|l|l|l|l|l|l|}
\hline \multirow{7}{*}{ Valid } & & Frequency & Percent & Valid Percent & Cumulative Percent \\
\cline { 2 - 6 } & $\begin{array}{l}\text { Better than } \\
\text { Competitors }\end{array}$ & 18 & 35.3 & 37.5 & 37.0 \\
\cline { 2 - 6 } & $\begin{array}{l}\text { About the same } \\
\text { as Competitors }\end{array}$ & 21 & 41.2 & 43.8 & 81.1 \\
\cline { 2 - 6 } & $\begin{array}{l}\text { Not so Good as } \\
\text { Competitors }\end{array}$ & 5 & 9.8 & 10.4 & 91.0 \\
\cline { 2 - 7 } & Not sure & 4 & 7.8 & 8.3 & 100.0 \\
\cline { 2 - 6 } & Total & 48 & 94.1 & 100.0 & \\
\hline Missing & System & 3 & 5.9 & & \\
\hline Total & & 51 & 100.0 & & \\
\hline
\end{tabular}

Pricing / Value for Money

\begin{tabular}{|l|l|l|l|l|l|}
\hline & & Frequency & Percent & Valid Percent & Cumulative Percent \\
\hline Valid & $\begin{array}{l}\text { Better than } \\
\text { Competitors }\end{array}$ & 12 & 23.5 & 24.0 & 24.0 \\
\cline { 2 - 6 } & $\begin{array}{l}\text { About the same } \\
\text { as Competitors }\end{array}$ & 29 & 56.9 & 58.0 & 82.0 \\
\cline { 2 - 6 } & $\begin{array}{l}\text { Not so Good as } \\
\text { Competitors }\end{array}$ & 2 & 3.9 & 4.0 & 86.0 \\
\cline { 2 - 7 } & Not sure & 7 & 13.7 & 14.0 & 100.0 \\
\cline { 2 - 7 } & Total & 50 & 98.0 & 100.0 & \\
\hline Missing & System & 1 & 2.0 & & \\
\hline Total & & 51 & 100.0 & & \\
\hline
\end{tabular}

Productivity / Unit Costs / Profit Margins

\begin{tabular}{|l|l|l|l|l|l|}
\hline & & Frequency & Percent & Valid Percent & Cumulative Percent \\
\hline Valid & $\begin{array}{l}\text { Better than } \\
\text { Competitors }\end{array}$ & 19 & 23.5 & 24.0 & 38.0 \\
\cline { 2 - 6 } & $\begin{array}{l}\text { About the same } \\
\text { as Competitors }\end{array}$ & 25 & 56.9 & 58.0 & 89.0 \\
\cline { 2 - 6 } & $\begin{array}{l}\text { Not so Good as } \\
\text { Competitors }\end{array}$ & 2 & 2.9 & 4.0 & 93.0 \\
\cline { 2 - 6 } & Not sure & 3 & 13.7 & 14.0 & 100.0 \\
\cline { 2 - 6 } & Total & 49 & 98.0 & 100.0 & \\
\hline Missing & System & 2 & 2.0 & & \\
\hline Total & & 51 & 100.0 & & \\
\hline
\end{tabular}

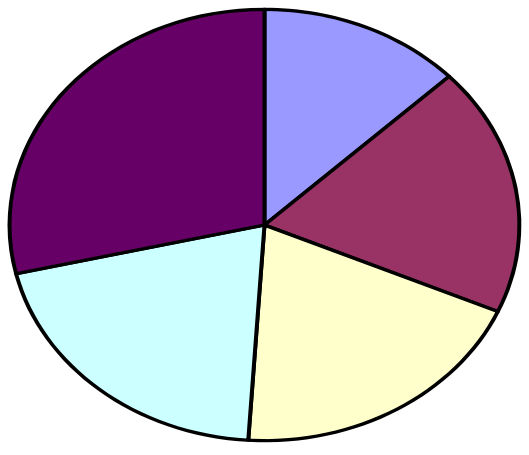

口2001-02 口2002-03 प2003-04 प2004-05

2005-06

Figure 1. Export of Bed Wear from Pakistan during 2001-06 